\title{
Blending Influence on the Conversion Efficiency of the Cogasification Process of Corn Stover and Coal
}

\author{
Anthony Ike Anukam, ${ }^{1,2}$ Sampson Ntshengedzeni Mamphweli, ${ }^{2}$ \\ Polycarp Sbusiso Mabizela, ${ }^{2}$ and Edson Leroy Meyer $^{2}$ \\ ${ }^{1}$ Department of Chemistry, University of Fort Hare, Private Bag X1314, Alice 5700, South Africa \\ ${ }^{2}$ Fort Hare Institute of Technology, University of Fort Hare, Private Bag X1314, Alice 5700, South Africa \\ Correspondence should be addressed to Anthony Ike Anukam; aanukam@ufh.ac.za
}

Received 3 March 2016; Revised 19 May 2016; Accepted 21 June 2016

Academic Editor: Davide Vione

Copyright (C) 2016 Anthony Ike Anukam et al. This is an open access article distributed under the Creative Commons Attribution License, which permits unrestricted use, distribution, and reproduction in any medium, provided the original work is properly cited.

\begin{abstract}
Characterizations of biomass and coal were undertaken in order to compare their properties and determine the combustion characteristics of both feedstocks. The study was also intended to establish whether the biomass (corn stover) used for this study is a suitable feedstock for blending with coal for the purpose of cogasification based on composition and properties. Proximate and ultimate analyses as well as energy value of both samples including their blends were undertaken and results showed that corn stover is a biomass material well suited for blending with coal for the purpose of cogasification, given its high volatile matter content which was measured and found to be $75.3 \%$ and its low ash content of $3.3 \%$ including its moderate calorific value of $16.1 \%$. The results of the compositional analyses of both pure and blended samples of corn stover and coal were used to conduct computer simulation of the cogasification processes in order to establish the best blend that would result in optimum cogasification efficiency under standard gasifier operating conditions. The final result of the cogasification simulation process indicated that $90 \%$ corn stover $/ 10 \%$ coal resulted in a maximum efficiency of about $58 \%$ because conversion was efficiently achieved at a temperature that is intermediate to that of coal and corn stover independently.
\end{abstract}

\section{Introduction}

Coal is the most widely used primary fuel internationally, accounting for about $36 \%$ of the total fuel consumption of the world's electricity production [1]. An excess of 255 million tons of coal is produced in South Africa and almost three-quarters of that is consumed domestically with $77 \%$ of South Africa's energy needs directly derived from coal [13]. In spite of being a nonrenewable feedstock, coal can be effectively combined with biomass feedstock to produce a synergistic effect during gasification [4]. This process results in fewer $\mathrm{CO}_{2}$ emissions. Gasification is an alternative energy conversion technology that converts organic materials into usable energy in the form of syngas. On the one hand, the technology has attracted enormous interest for the past several years within thermochemical conversion technologies as it has been proven to offer higher efficiencies in comparison to combustion [5], while, on the other hand, it has been a promising renewable energy technology for the supply of thermal energy and generating electrical power. However, there are challenges associated with the use of the gasification technology for energy production purposes. These challenges include biomass supply, which is limited and varies with season; low energy density of biomass, which results in low production, expensive transportation to the gasification plant where it is to be used as feedstock, especially for long distances, and so forth. These challenges result in higher capital and production cost. Coal gasification, on the other hand, though an established technology, is also faced with the issue of greenhouse gas emissions. The risk of reaching extremely high temperatures that may result in pressure build-up is another shortcoming related to coal gasification as this process may lead to explosions. Taking these challenges into account, therefore, it is more economically attractive and less technically challenging to cogasify biomass with coal.

Cogasification of biomass with coal has its own challenges which are related to the uncertainties associated with how 
to mix them. The optimum percentages of various biomass and coal blends required for enhanced conversion efficiency under standard gasifier operating conditions remain an issue yet to be addressed. Other issues related to cogasification of biomass and coal include gasifier type as well as choice of gasifier operating parameters which, to a great extent, determines the product gas composition and quality. Biomass and coal differ greatly in terms of properties and composition. While coal contains mainly carbon, biomass is a complicated mixture of complex compounds such as cellulose, hemicellulose, and lignin as well as extractives and minerals with relatively high amount of oxygen which makes them low energy density fuels [6]. These properties play a vital role during cogasification because they come as factors which influence the cogasification process $[7,8]$. Various researchers have reported an increase in the efficiency of a cogasification process by increasing the ratio of biomass in the blend. $\mathrm{Li}$ et al., 2010 [9], have reported an elevated $\mathrm{H}_{2}$ and $\mathrm{CO}$ yield when the biomass ratio was increased from $20 \%$ to $33 \%$ during cogasification. Kumabe et al., in 2007 [7], studied the influence of the amount of biomass with respect to the molar ratio of $\mathrm{CO}, \mathrm{H}_{2}$, and $\mathrm{CO}_{2}$ in the product gas when they cogasified varying proportions of blended Mulia coal and Japanese cedar in a downdraft gasifier system at $1173 \mathrm{~K}$. They reported that the syngas composition varied according to the ratio of biomass in the blends. This study, therefore, sought to establish the properties and composition as well as proportion of corn stover and coal that would be suitable for cogasification and that would in itself result in optimum efficiency of the cogasification process, employing computer simulation.

\section{Materials and Method}

2.1. Sample Preparation and Characteristics. The biomass material used for this study was corn stover, and the coal used was a low grade subbituminous coal. Both samples were obtained in the Eastern Cape province of South Africa. A coning and quartering method was applied for size reduction of the samples using a Condux-Werk Wolfgang bei Hanau mill so as to obtain smaller fractions as required by the analytical instruments for analysis. The size obtained for the samples was in the range of $25 \mu \mathrm{m}$ to approximately $1 \mathrm{~mm}$. The sizes were measured using a micro mesh sieve of standard frame diameter between $25 \mu \mathrm{m}$ and $1 \mathrm{~mm}$. The blends of corn stover and coal were prepared in the following ratios: $100 \%$ CS (pure material), $90 \%$ CS/10\% CL, $80 \%$ CS/20\% CL, $70 \%$ CS/30\% CL, $60 \%$ CS/40\% CL, $50 \%$ CS/50\% CL, $40 \%$ CS/60\% CL, 30\% CS/70\% CL, $20 \%$ CS/80\% CL, 10\% CS/90\% CL, and $100 \%$ CL (pure material), where CS and CL represent corn stover and coal, respectively. Calculating the usefulness of a fuel requires an understanding of its characteristics [10]. The following subsections present the most important analyses relevant to the thermal conversion of the materials under study.

All experiments were repeated in triplicate and the results presented are represented by the average values of the tests conducted.

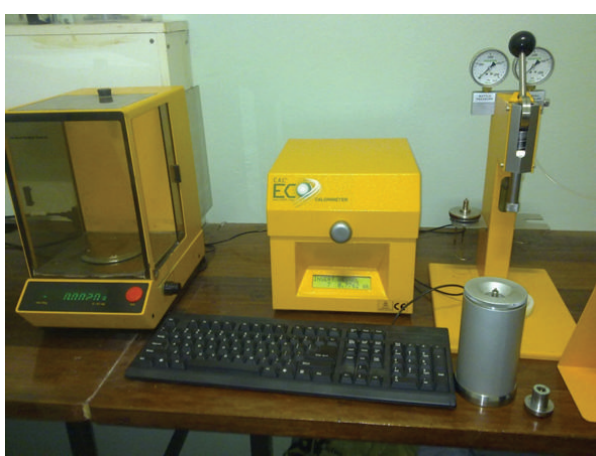

FIgURE 1: An oxygen bomb calorimeter.

2.1.1. Calorific Value of Samples. The calorific values of both pure and blended samples of corn stover and coal were determined by a CAL2K model oxygen bomb calorimeter, which was used to specifically determine the heat of combustion of the samples. The features of the calorimeter used include a microprocessor based bomb vessel that automatically measures the calorific value of samples, an LCD display with a standard keyboard connected to a screen, and a memory for data storage as well as a real time clock and a filling station designed to fill the vessel with oxygen. Figure 1 shows the oxygen bomb calorimeter used during the analysis.

The experiment was done by calibration with a $0.5 \mathrm{~g}$ of benzoic acid before taking measurements. A $3000 \mathrm{kpa}$ pressurized oxygen environment was used to achieve this. The calorimeter was operated via a keyboard as a stand-alone unit with all test information displayed on the LCD. About $1 \mathrm{~g}$ of the sample was placed inside the vessel, which is capable of firing counts as well as identifying and reconditioning data, before pressurizing with oxygen.

2.1.2. Elemental Analysis. The weight fractions of the individual elements contained in both pure and blended samples were determined by a ThermoQuest elemental analyzer. About $5 \mathrm{mg}$ of each sample was combusted in the instrument at approximately $1000^{\circ} \mathrm{C}$ after mixing with an oxidizer in a tin capsule. Figure 2 presents the elemental analyzer used for this study.

A violent reaction in a temporary enriched $\mathrm{O}_{2}$ environment was stimulated as the sample and tin capsule melted. There are catalysts downstream of the combustion chamber of the instrument to ensure complete oxidation of all heat resistant substances under the sample and tin melting conditions. These products were made to pass over a high purity $\mathrm{Cu}$ plate at about $600^{\circ} \mathrm{C}$. Cu plate functions to remove any $\mathrm{O}_{2}$ that was not consumed during the combustion process as well as to convert any nitrogen oxides to $\mathrm{N}_{2}$ gas. High purity substances are always employed during CHNS analysis to oxidize and rid the analysis of unwanted elements as well as keep the system clean so as to prevent interferences with analysis results [11]. Tungsten trioxide $\left(\mathrm{WO}_{3}\right)$ and copper $(\mathrm{Cu})$ were used as catalysts downstream of the combustion chamber to ensure complete oxidation. The catalysts' oxidizer $\left(\mathrm{WO}_{3}\right)$ and reducer $(\mathrm{Cu})$ were both kept at a temperature of $1000^{\circ} \mathrm{C}$. 


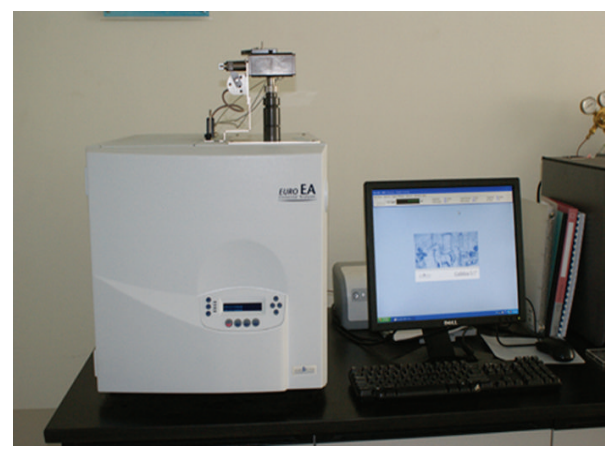

Figure 2: A ThermoQuest elemental analyzer.

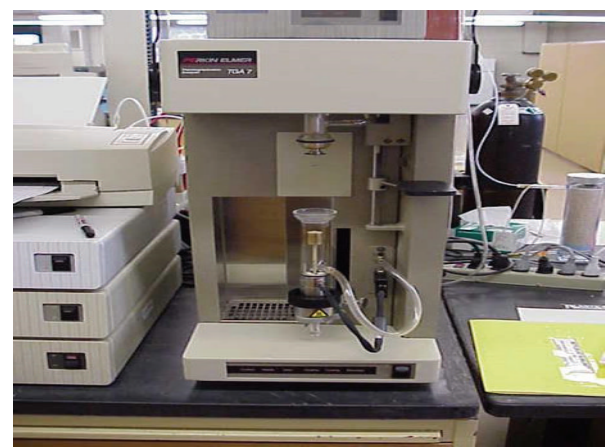

Figure 3: A thermogravimetric analyzer.

Combustion products such as $\mathrm{CO}_{2}, \mathrm{NO}_{2}$, and $\mathrm{SO}_{2}$ were produced in the process and were conveyed by a constant flow of helium-rich carrier gas before being catalytically reduced to $\mathrm{C}, \mathrm{N}$, and $\mathrm{S}$. The gases $\left(\mathrm{CO}_{2}, \mathrm{NO}_{2}, \mathrm{SO}_{2}\right.$, etc. $)$ were separated by gas chromatography and the concentration of the elements sought was measured by a thermal conductivity detector.

2.1.3. Thermal Analysis. A Perkin Elmer TGA 7 thermogravimetric analyzer was used to study the thermal degradation behavior of both pure and blended samples of corn stover and coal. A $5.08 \mathrm{mg}$ of each sample was heated over a temperature range of $20^{\circ} \mathrm{C}-1000^{\circ} \mathrm{C}$ under a nitrogen atmosphere at $20^{\circ} \mathrm{C} /$ min heating rate. This analysis was undertaken in order to establish the thermal behavior and the temperature of the cogasification processes of both pure and blended samples of corn stover and coal. The thermogravimetric analyzer used for the thermal analysis of both pure and blended samples of corn stover and coal is presented in Figure 3.

An inconsequential amount of sample and a low heating rate $\left(20^{\circ} \mathrm{C} / \mathrm{min}\right)$ were employed to avoid limitations in heat transfer and to minimize the impact of mass transfer. Another reason for the low heating rate used was because it is a characteristic of fixed bed gasification systems. It is worth noting that the TGA process only represents the pyrolysis stage in the gasification process.

2.1.4. Cogasification Simulation Process. A mathematical model modified by Jayah et al., 2003 [12], and designed specifically to simulate the gasification performance of a typical

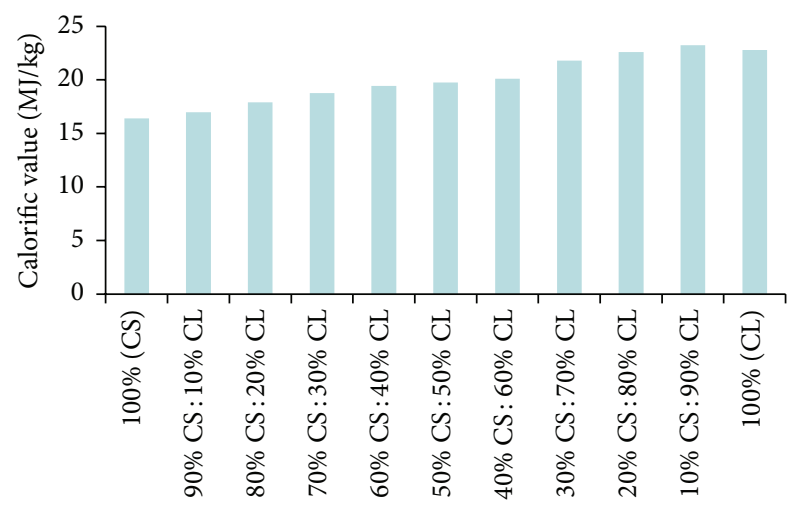

FIGURE 4: Energy content of pure and blended samples of corn stover and coal.

downdraft gasifier system was used to conduct computer simulation of the cogasification processes of both pure and blended samples of corn stover and coal for maximum efficiency. The proximate and ultimate analyses as well as the calorific value results of the samples obtained in Section 3 were used during calculation of the conversion efficiency of the cogasification processes of the samples. A detailed description of the simulation programme has been presented in our previous paper [10]. For optimum cogasification efficiency, the normal operating parameters/conditions of a downdraft gasifier are presented in Table 1.

A direct type of gasification of the pure and blended samples was carried out via computer simulation and the maximum temperature reached during the process was about $1200^{\circ} \mathrm{C}$. The gasification temperature increased (from an initial of $150^{\circ} \mathrm{C}$ ) with increasing supply of $\mathrm{O}_{2}$ and feedstock until a maximum temperature of $1200^{\circ} \mathrm{C}$ was attained in the gasifier.

\section{Results and Discussion}

3.1. Energy Content of Pure and Blended Samples. The calorific values gave a clear indication of the energy contained in the samples and were obtained after analysis by the oxygen bomb calorimeter. Increasing the biomass content during cogasification would enhance the calorific value of the syngas produced due to higher composition of hydrocarbons in biomass $[17,18]$. The results of the calorific value of the pure and blended samples of corn stover and coal are presented in Figure 4 .

The difference in calorific value between the pure materials as well as their blends is quite noticeable from Figure 4 . The pure coal sample has a much higher calorific value $(22.8 \mathrm{MJ} / \mathrm{kg}$ ) compared to $100 \%$ corn stover with ca $17 \mathrm{MJ} / \mathrm{kg}$. This difference in calorific value could also be correlated to the concentration of $\mathrm{C}$ and $\mathrm{O}_{2}$ in the samples (elemental composition in Figure 5). 1\% increase in carbon concentration will elevate the calorific value by approximately $0.39 \mathrm{MJ} / \mathrm{kg}$ and coals generally have calorific values greater than biomass because of lower degree of oxidation; in contrast, the calorific values of the blends vary in accordance with the ratio of coal to corn stover in the blends. Calorific value increases 
TABLE 1: Normal operating parameters of a downdraft gasifier [12].

\begin{tabular}{lccc}
\hline Fuel properties & Value & Gasifier operating conditions & Value \\
\hline Carbon (\%) & 39.6 & Throat diameter $(\mathrm{cm})$ & 94.0 \\
Hydrogen (\%) & 6.7 & Throat angle $\left({ }^{\circ}\right)$ & 90.0 \\
Oxygen (\%) & 52.1 & Insulation thickness $(\mathrm{cm})$ & 0 \\
Nitrogen (\%) & 1.59 & Thermal conductivity $(\mathrm{W} / \mathrm{cm} \mathrm{K})$ & 0.87 \\
Fixed carbon $(\%)$ & 19.3 & Temperature of input air $(\mathrm{K})$ & 293 \\
Bulk density $\left(\mathrm{kg} / \mathrm{m}^{3}\right)$ & 0.25 & Air input $(\mathrm{kg} / \mathrm{hr})$ & 44.5 \\
Diameter of particle $(\mathrm{cm})$ & 1.0 & Heat loss $(\%)$ & 12.8 \\
Moisture content $(\%)$ & 8.7 & Feed input $(\mathrm{kg} / \mathrm{hr})$ & 40 \\
& & Maximum gasifier temperature $\left({ }^{\circ} \mathrm{C}\right)$ & 1200 \\
\hline
\end{tabular}

TABle 2: Proximate analysis of pure and blended samples of corn stover and coal.

(a)

\begin{tabular}{lccccccc}
\hline \multicolumn{9}{c}{ Coal (wt\%) } & \multicolumn{5}{c}{ Corn stover (wt\%) } \\
\hline MC & VM & FC & AS & MC & VM & FC & AS \\
0.2 & 25 & 24 & 50.8 & 8.7 & 75.3 & 19.3 & 3.3 \\
\hline
\end{tabular}

(b)

\begin{tabular}{lcccc}
\hline & \multicolumn{4}{c}{ Blended samples } \\
Blend & \multicolumn{4}{c}{ CL: CS (wt\%) } \\
\hline Ratio (\%) & MC & VM & FC & AS \\
$90: 10$ & 2.5 & 23 & 29.5 & 45.2 \\
$80: 20$ & 2.6 & 27.3 & 27 & 43.1 \\
$70: 30$ & 3.1 & 32.5 & 25.4 & 39 \\
$60: 40$ & 3.4 & 35.4 & 36.9 & 24.3 \\
$50: 50$ & 4.2 & 48.9 & 29.6 & 17.3 \\
$40: 60$ & 5.4 & 53.6 & 28.2 & 12.8 \\
$30: 70$ & 5.9 & 55.1 & 28.4 & 10.6 \\
$20: 80$ & 6.5 & 66.4 & 19.8 & 7.3 \\
$10: 90$ & 7.6 & 69.8 & 17.9 & 4.7 \\
\hline
\end{tabular}

Note. MC: moisture content; VM: volatile matter content; FC: fixed carbon; AS: ash content; CL: coal; CS: corn stover.

with increasing ratio of coal in the blends [19]. Therefore, $10 \% \mathrm{CS} / 90 \%$ CL has the highest calorific value because of the higher percentage of coal in the blend.

3.2. Proximate Analysis of Pure and Blended Samples. Table 2 shows the proximate analysis results of both pure and blended samples of corn stover and coal. These were obtained from the TGA plots in Figure 6. This analysis was undertaken in order to compare the physical properties of corn stover with those of coal including their blends and establish the properties that would influence the cogasification processes of both pure and blended samples under standard gasifier operating conditions. The weight percentages of fixed carbon in the pure and blended samples were obtained by difference.

The values obtained for both pure and blended samples in Table 2 are within acceptable ranges found in the literature. Comparing the properties of the pure samples with those of

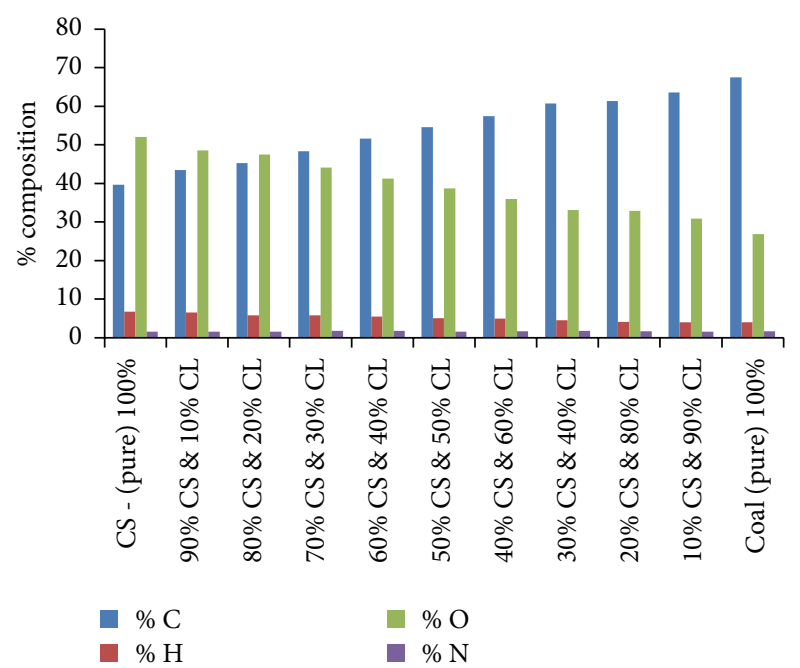

FIGURE 5: Ultimate analysis of pure and blended samples of corn stover and coal.

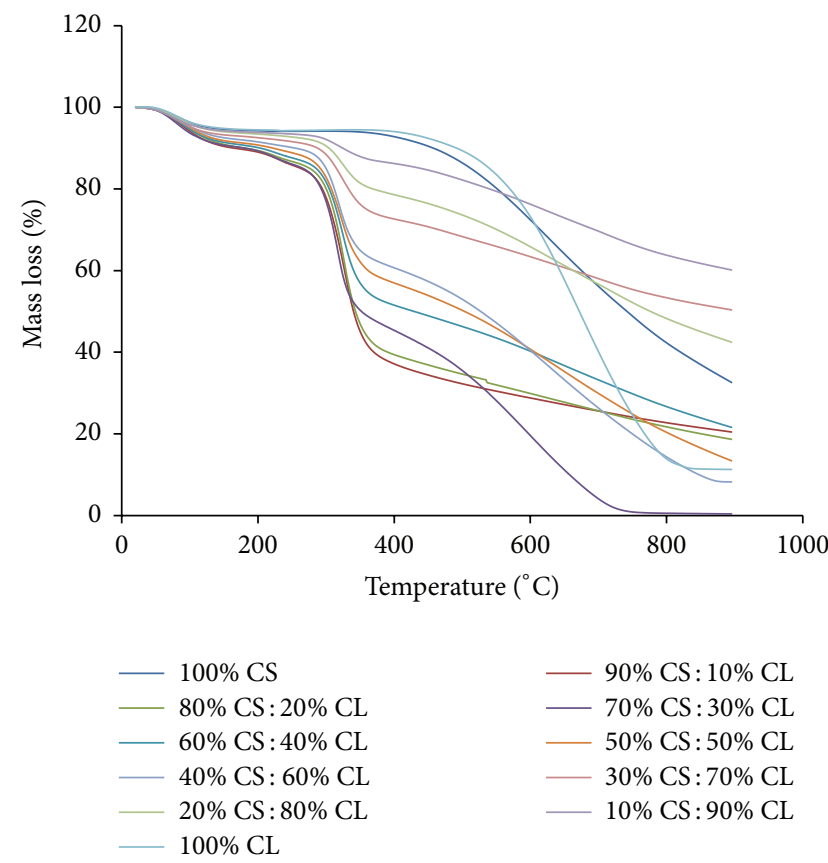

FIgURE 6: TGA of pure and blended samples of corn stover and coal. 
the blended, it could be easily noticed that a typical South African subbituminous coal used for this study has high amount of ash in comparison to corn stover which showed quite a relatively low ash composition. Ash content of coal varies over a wide range and this variation occurs in coals not only from different geographical areas or from different seams in the same region but also from different parts of the same mine, which results primarily from a wide range of conditions that introduces foreign materials during or following the formation of coal [20]. The reason for the high amount of ash in the pure coal is most likely due to the influence of extraneous mineral matter introduced during mining operations where the coal was obtained. The difference in the pure and blended samples is also quite evident from Table 2 as the blends with higher percentages of coal exhibited higher ash contents. Some of the blends with higher ratios of corn stover also exhibited higher ash contents. The reason for this is quite vague and requires further investigation. However, high amount of ash is undesirable as it could create agglomeration, slagging, and fouling as well as deposition and corrosion during gasification; therefore, to avoid these challenges during cogasification, feedstock ash content must be below $6 \%[10,21]$.

The difference in volatile matter content between coal and corn stover can also be observed in Table 2. This is linked to differences in properties between the two feedstocks. Fuels with high volatile matter content are always better for gasification because they tend to vapourize before combustion compared to fuels with low volatile matter content that burn primarily as glowing char and this affects the performance of the combustion chamber of the gasifier which is usually taken into account when designing gasification systems [22]. Moisture content of the pure coal material is relatively low compared to the corn stover and varies in the blends according to the percentage of corn stover in the blends. High feedstock moisture content lowers the temperature inside the combustion unit of the gasifier and will lead to an increased fuel throughput, thereby increasing the volume of flue gas released [23]. The fixed carbon of coal is higher (24\%) than that of corn stover which again is as a consequence of the difference in physical properties between corn stover and coal. In contrast, the fixed carbon content of the blends showed a slight variation due to the ratio of volatiles in the pure coal. Fixed carbon is calculated as a function of moisture, volatile matter, and ash content, and the uncertainties of these properties affect the uncertainty in the concentration of fixed carbon [10]. This factor is probably the reason for the large increase in $\mathrm{FC}$ between blends $60 \% \mathrm{Cl} / 40 \% \mathrm{CS}$ and the $30 \%$ $\mathrm{CL} / 70 \% \mathrm{CS}$. The fixed carbon content of the blends were also in narrow ranges due to the amount of volatile matter and moisture as well as ash driven off in the sample during thermal analysis.

3.3. Ultimate Analysis of Pure and Blended Samples. Figure 5 shows the ultimate analysis data obtained after CHNS analysis of the pure and blended samples of corn stover and coal.

The elemental analysis of corn stover and coal including their blends showed that the main chemical constituents of the samples are $\mathrm{C}, \mathrm{H}_{2}$, and $\mathrm{O}_{2}$, which is due mainly to the organic nature of both feedstocks. However, the percentage composition of $\mathrm{C}$ in pure coal $(67.5 \%)$ is almost double that of pure corn stover (39.6\%), which supports the fact that coal, chiefly, contains C. According to the trend in Figure 5, the percentage composition of $\mathrm{C}$ increased with increasing percentage of coal in the blends, while that of $\mathrm{O}_{2}$ decreased with decreasing ratios of corn stover in the blends. $\mathrm{H}_{2}$ composition also decreased quite slightly with decreasing percentage of corn stover in the blends. This is attributed to the differences in properties between corn stover and coal. $\mathrm{C}$ and $\mathrm{H}_{2}$ are oxidized during cogasification by exothermic reactions forming $\mathrm{CO}_{2}$ and $\mathrm{H}_{2} \mathrm{O}$. The content of $\mathrm{C}$ and $\mathrm{H}_{2}$ has a positive contribution to the calorific value of the fuel and the $\mathrm{CO}_{2}$ formed is emitted as a major product of complete combustion because incomplete combustion in the oxidation zone of the gasifier can lead to emissions of unburnt carbon based pollutants such as hydrocarbons, polycyclic aromatic hydrocarbons, tar, and soot [10]. $\mathrm{O}_{2}$ will reduce the energy density of the fuel [24]. However, the presence of $\mathrm{O}_{2}$ is important to start the syngas formation process as it reacts with $\mathrm{C}$ and $\mathrm{H}_{2}$ in the feedstock to form $\mathrm{CO}_{2}$ and $\mathrm{H}_{2} \mathrm{O} . \mathrm{CO}_{2}$ formed reacts with $\mathrm{C}$ in the feedstock to produce $\mathrm{CO}$. Fuel $\mathrm{N}$ is almost entirely converted into gaseous $\mathrm{N}\left(\mathrm{N}_{2}\right)$ and nitric oxides $\left(\mathrm{NO}_{x},\left[\mathrm{NO}, \mathrm{NO}_{2}\right]\right)$ during cogasification. One of the main environmental effects of combustion of coal and biomass is caused by the emission of $\mathrm{NO}_{x}$ [25]. $\mathrm{NO}_{x}$ can be formed through reaction pathways such as reaction of $\mathrm{N}_{2}$ with $\mathrm{O}_{2}$ radicals at high temperatures (above $1300^{\circ} \mathrm{C}$ ) and the amount increases with increasing temperature. It could also be formed from airborne $\mathrm{N}_{2}$ at yet again temperatures above $1300^{\circ} \mathrm{C}$ but under low $\mathrm{O}_{2}$ conditions in the presence of hydrocarbons $[26,27]$. The most important mechanism in gasification systems is the formation of $\mathrm{NO}_{x}$ from the oxidation of fuel $\mathrm{N}_{2}$ during a series of elementary reaction steps and emission increases with increasing fuel $\mathrm{N}_{2}$ content [28]. However, the major influencing parameters for $\mathrm{NO}_{x}$ formation include air supply, combustion zone geometry, and temperature, as well as type of gasification technology used [29]. Emission related problems for solid fuels exceeding emission limits can be expected at fuel $\mathrm{N}$ concentrations above $0.6 \mathrm{wt} . \%$. $\mathrm{N}$ composition in the blends is quite minimal and poses no environmental concern during cogasification.

3.4. Thermal Behavior of Pure and Blended Samples of Corn Stover and Coal. The rate of degradation of a sample during thermogravimetric analysis is an indication of the thermal behavior of the sample under gasification [10]. Figure 6 shows the weight loss of pure and blended samples of corn stover and coal obtained after thermal analysis using a thermogravimetric analyzer and carried out under a nitrogen flow rate of $20 \mathrm{~mL} / \mathrm{min}$. The maximum temperature reached was $900^{\circ} \mathrm{C}$ at $20^{\circ} \mathrm{C} / \mathrm{min}$ heating rate.

It is quite clear from Figure 6 that pure coal degrades over a wider temperature range when compared to pure corn stover. The blends with higher percentages of coal assumed essentially the same shape with degradation occurring at a much wider temperature range due to reduced content of volatile matter in coal (according to Table 2). However, an initial mass loss occurred at $105^{\circ} \mathrm{C}$ temperature for all 
samples except for 70\% CS :30\% CL (70\% corn stover : $30 \%$ coal) with initial mass loss occurring at a much higher temperature $\left(130^{\circ} \mathrm{C}\right)$. The reason for this is attributed to analysis conditions such as amount (mg) of sample analyzed as well as full combustion of the sample during TGA analysis. The sample was completely burnt as compared to the other samples; hence, the plot is resting on the temperature axis. This initial mass loss was due to the evaporation of moisture from the samples. Rapid weight loss due to devolatilization in $100 \%$ corn stover began at $400^{\circ} \mathrm{C}$, which is considerably lower than the temperature corresponding to the start of devolatilization of $100 \%$ coal at $530^{\circ} \mathrm{C}$. At all mix ratios, the curves corresponding to the blends maintained essentially the same shape and position and displayed three stages of weight losses with the last stage of devolatilization occurring at a much higher temperature $\left(600-800^{\circ} \mathrm{C}\right)$ due to char oxidation. This observation is again excluding 70\% CS : 30\% CL blend, which is characterized by four weight loss stages due to much higher volatile matter content of corn stover in the blend. Its last stage of weight loss occurs at $715^{\circ} \mathrm{C}$. In general, and in relation to cogasification, starting from room temperature to a temperature corresponding to $900^{\circ} \mathrm{C}$, degradation of all samples would be a function of the percentage of coal in the blends because of the difference in the molecular structure of biomass and coal, which affects their reactivity; coal structure mainly consists of the $\mathrm{C}=\mathrm{C}$ bond derived from its significant polyaromatic hydrocarbon nature that requires more energy to be broken, compared to $\mathrm{C}=\mathrm{O}$ bond common to the structure of biomass because of its content of cellulose, hemicellulose, and lignin that requires low energy to be broken [30]. However, complete degradation of the samples may occur at temperatures above $1000^{\circ} \mathrm{C}$ during gasification, leaving some amount of ash whose concentration would depend on the composition of the mineral matter content of the feedstocks for cogasification and the conditions of cogasification.

3.5. Computer Simulation of the Cogasification Processes of Pure and Blended Samples of Corn Stover and Coal. Gasification efficiency is an expression of the energy content of gaseous products to energy content of biomass, coal, or a mixture of them as solid fuel [31]. It is an important factor that determines the actual technical operation and the economic viability of using a gasification system. The computer simulation programme described in Section 2.1.4 was used to undertake the simulation of the cogasification processes of both pure and blended samples of corn stover and coal. Figure 7 shows the efficiency plot of the cogasification processes of all samples obtained after computer simulation.

As evident from Figure 7, there are no significant differences in the efficiency of some of the blends, while, for some other blends, a significant difference could be noticed. Blend $90 \%$ CS/10\% CL resulted in maximum efficiency of approximately $58 \%$. This optimum efficiency was achieved because conversion was efficiently reached at a temperature that is intermediate to that of coal and corn stover independently. Another reason for the optimum efficiency may also be due to catalytically active components in corn

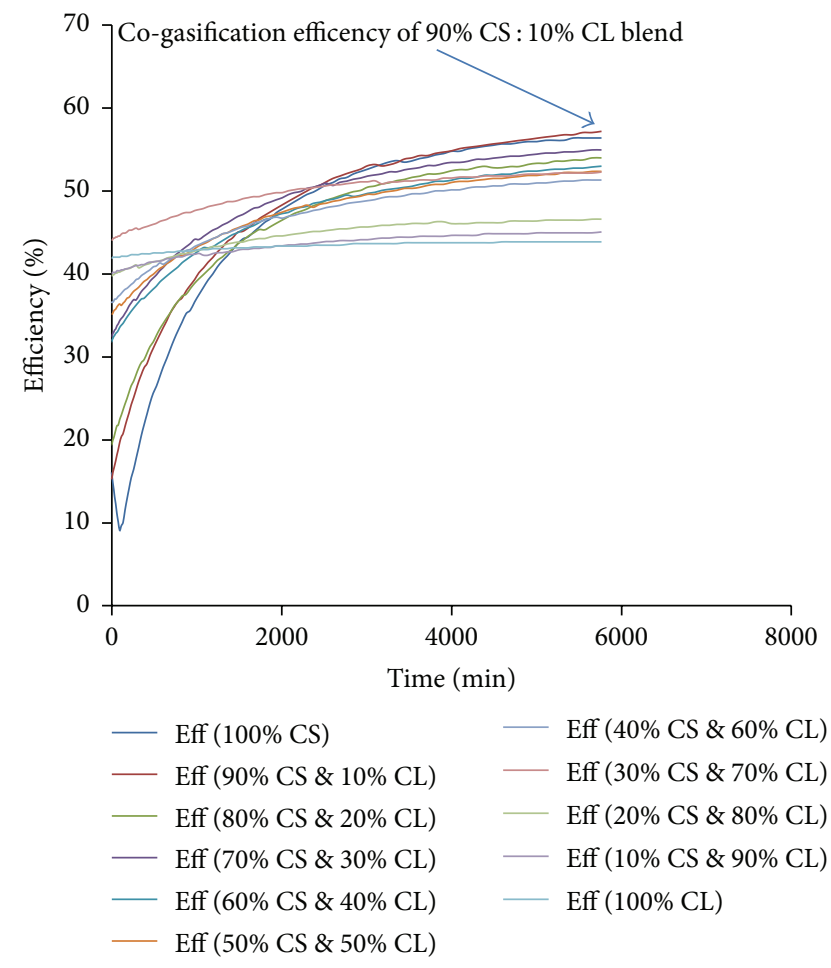

FIGURE 7: Simulated efficiency of the cogasification processes of pure and blended samples of corn stover and coal.

stover. The conversion efficiency of a gasification process among other factors also depends on the catalytically active components in the feedstock [32]. The gasifier operating parameters/conditions presented in Table 1 were also other factors responsible for the optimum cogasification efficiency shown by the blend ( $90 \%$ corn stover $10 \%$ coal), as well as the ratio of corn stover in the blend. Raising the ratio of biomass in a cogasification process increases the efficiency of the process [33].

3.6. Comparison with Experimental Data. A comparison between the simulated process studied and experimental data from the literature was undertaken for this study and results are presented in Table 3.

It can be clearly seen from Table 3 that there is only about 5 to $8 \%$ variation between measured and simulated results, except for 10:90 groups. The type of biomass blended with coal is a determinant factor in achieving optimum cogasification efficiency because of the variation in the properties of the biomass, which plays a consequential role [34]. Therefore, it is fair to say that the model used for the simulation of the cogasification processes of pure and blended samples of corn stover and coal can be applied for further analysis with acceptable accuracy. The validated model was used to study the effect of process efficiency. The simulation results concur with the experimental data found in the literature and are useful in predicting experimental observations reasonably well based on process efficiency. However, the large gap found between measured data from the literature and simulated data from this study for 10:90 groups according to Table 3 
TABLE 3: A comparison of the simulated results from this study with experimental data from the literature.

\begin{tabular}{|c|c|c|}
\hline Blend ratio (\%) & Materials blended & Gasification efficiency (\%) \\
\hline \multicolumn{3}{|c|}{ This study } \\
\hline $90: 10$ & \multirow{9}{*}{ Corn stover : coal } & 58 \\
\hline $80: 20$ & & 53.5 \\
\hline $70: 30$ & & 54.4 \\
\hline $60: 40$ & & 52.6 \\
\hline $50: 50$ & & 51.3 \\
\hline $40: 60$ & & 50.8 \\
\hline $30: 70$ & & 49.3 \\
\hline $20: 80$ & & 46.1 \\
\hline $10: 90$ & & 44.9 \\
\hline \multicolumn{3}{|c|}{ Previous authors } \\
\hline $90: 10$ & Wood: coal [13] & $50-95$ \\
\hline $80: 20$ & Wood: coal [13] & 43 \\
\hline $70: 30$ & Pine chips : coal [9] & Improved $\mathrm{H}_{2}$ eff. From $17 \%$ to $22 \%$ \\
\hline \multirow{2}{*}{$60: 40$} & Mulia coal: Japanese cedar [7] & 47.9 \\
\hline & Coal: pine chips $[14]$ & Improved efficiency \\
\hline \multirow{2}{*}{$50: 50$} & Woody biomass : coal [7] & $65-85$ \\
\hline & Indonesian Tinto coal : sawdust [14] & 45 \\
\hline \multirow{2}{*}{$40: 60$} & Coal : pinewood [13] & $48-62$ \\
\hline & Coal: pine chips [15] & Improved efficiency \\
\hline $30: 70$ & Bagasse : coal [16] & 55.03 \\
\hline $20: 80$ & Pine chips : coal [9] & Continuous and stable operation/Improved efficiency \\
\hline \multirow{3}{*}{$10: 90$} & Coal: pine sawdust [17] & 82.3 \\
\hline & Coal : almond shell [17] & 77.7 \\
\hline & Coal : olive stones [17] & 81.6 \\
\hline
\end{tabular}

suggests that the efficiency of a gasification process depends on the type of biomass and coal used.

\section{Conclusions}

The influence of blending on the conversion efficiency of the cogasification process of corn stover and coal in a computer simulated downdraft gasifier system was investigated in this study, and the most suitable blend for cogasification established based on efficiency. The best blend was 90\% CS/10\% CL because conversion was independently achieved at a temperature that is intermediate to that of corn stover and coal. However, results also showed that the suitability of corn stover and coal for cogasification depends on a number of factors which included the composition and properties of both feedstocks and the ratio of blending as well as the operating conditions of the gasifier. Furthermore, a comparison of the simulated data from this study and experimental data from the literature showed similar results in terms of efficiency, implying that a laboratory scale or a large scale downdraft gasification system for the purpose of cogasification of corn stover and coal can be designed using simulation results. The study established that corn stover is a carbonaceous feedstock suitable for cogasification with coal in a downdraft gasification system properly designed to accommodate the properties of both feedstocks.

\section{Competing Interests}

The authors declare that they have no competing interests.

\section{Acknowledgments}

The authors wish to acknowledge the Fort Hare Institute of Technology and the Chemistry Department, University of Fort Hare, as well as Eskom and the National Research Foundation of South Africa including the Govan Mbeki Research and Development Centre of the University of Fort Hare for providing financial support for this research. Their support is deeply appreciated.

\section{References}

[1] Department of Energy and Republic of South Africa, An overview of coal resources, 2010, http://www.energy.gov.za/ files/coal_frame.html.

[2] BP Statistical review of World Energy. A review. British Petroleum, 2012, http://bp.com/statisticalreview.

[3] United Nations Development Programme (UNDP), World Energy Assessment: Energy and the Challenge of Sustainability, 2000, http://www.undp.org/content/dam/aplaws/publication/ en/publications/environment-energy/www-ee-library/sustainable-energy/world-energy-assessment-energy-and-the-chal- 
lenge-of-sustainability/World\%20Energy\%20Assessment-2000 .pdf.

[4] K. Sjöström, G. Chen, Q. Yu, C. Brage, and C. Rosén, "Promoted reactivity of char in co-gasification of biomass and coal: synergies in the thermochemical process," Fuel, vol. 78, no. 10, pp. 1189-1194, 1999.

[5] Y. Ardila, J. Figueroa, B. Lunelli, F. Maciel, and M. Maciel, Syngas Production from Sugarcane Bagasse in a Circulating Fluidized Bed Gasifier Using Aspen ${ }^{\mathrm{TM}}$, Laboratory of Optimization, Design and Advanced Control. School of Chemical Engineering, State University of Campinas, Sao Paulo, Brazil, 2011.

[6] M. Siedlecki, W. de Jong, and A. H. M. Verkooijen, "Fluidized bed gasification as a mature and reliable technology for the production of bio-syngas and applied in the production of liquid transportation fuels-a review," Energies, vol. 4, no. 3, pp. 389-434, 2011.

[7] K. Kumabe, T. Hanaoka, S. Fujimoto, T. Minowa, and K. Sakanishi, "Co-gasification of woody biomass and coal with air and steam," Fuel, vol. 86, no. 5-6, pp. 684-689, 2007.

[8] J. F. Vélez, F. Chejne, C. F. Valdés, E. J. Emery, and C. A. Londoño, "Co-gasification of Colombian coal and biomass in fluidized bed: an experimental study," Fuel, vol. 88, no. 3, pp. 424-430, 2009.

[9] K. Li, R. Zhang, and J. Bi, "Experimental study on syngas production by co-gasification of coal and biomass in a fluidized bed," International Journal of Hydrogen Energy, vol. 35, no. 7, pp. 2722-2726, 2010.

[10] A. Anukam, S. Mamphweli, E. Meyer, and O. Okoh, “Computer simulation of the mass and energy balance during gasification of sugarcane bagasse," Journal of Energy, vol. 2014, Article ID 713054, 9 pages, 2014.

[11] Perkin Elmer, "2400 Series II CHNS/O Elemental Analysis: organic elemental analysis," 2016, https://www.perkinelmer .com/lab-solutions//resources/docs/BRO_2400_SeriesII_ CHNSO_Elemental_Analysis.pdf.

[12] T. H. Jayah, L. Aye, R. J. Fuller, and D. F. Stewart, "Computer simulation of a downdraft wood gasifier for tea drying," Biomass and Bioenergy, vol. 25, no. 4, pp. 459-469, 2003.

[13] I. Aigner, C. Pfeifer, and H. Hofbauer, "Co-gasification of coal and wood in a dual fluidized bed gasifier," Fuel, vol. 90, no. 7, pp. 2404-2412, 2011.

[14] M. W. Seo, J. H. Goo, S. D. Kim, S. H. Lee, and Y. C. Choi, "Gasification characteristics of coal/biomass blend in a dual circulating fluidized bed reactor," Energy and Fuels, vol. 24, no. 5, pp. 3108-3118, 2010.

[15] Y. G. Pan, E. Velo, X. Roca, J. J. Manyà, and L. Puigjaner, "Fluidized-bed co-gasification of residual biomass/poor coal blends for fuel gas production," Fuel, vol. 79, no. 11, pp. 13171326, 2000.

[16] H. A. Long and T. Wang, "Case studies for biomass/coal cogasification in IGCC applications," in Proceedings of the ASME 2011 Turbo Expo: Turbine Technical Conference and Exposition, Paper No. GT2011-45512, pp. 547-561, Vancouver, Canada, June 2011.

[17] J. Fermoso, B. Arias, M. G. Plaza et al., "High-pressure cogasification of coal with biomass and petroleum coke," Fuel Processing Technology, vol. 90, no. 7-8, pp. 926-932, 2009.

[18] A. Valero and S. Usón, "Oxy-co-gasification of coal and biomass in an integrated gasification combined cycle (IGCC) power plant," Energy, vol. 31, no. 10-11, pp. 1643-1655, 2006.
[19] B. M. Jenkins, "Physical properties of biomass," in Biomass Handbook, O. Kitani and C. W. Hall, Eds., chapter 5.2, Gordon \& Breach, New York, NY, USA, 1989.

[20] S. P. Schweinfurth, An Introduction to Coal Quality, Chapter C of The National Coal Resource Assessment Overview, U.S. Geological Survey Professional Paper 1625-F, 2009.

[21] E. Gustafsson, L. Lin, and M. Strand, "Characterization of particulate matter in the hot product gas from atmospheric fluidized bed biomass gasifiers," Biomass and Bioenergy, vol. 35, no. 1, pp. S71-S78, 2011.

[22] D. Ciolkosz, "Characteristics of biomass as a heating fuel," Renewable and Alternative Energy Fact Sheet, Penn State College of Agricultural Sciences, Agricultural Research and Coorporative Extension, State College, Pa, USA, 2010, http://www .energy.extension.psu.edu.

[23] A. A. Khan, W. de Jong, P. J. Jansens, and H. Spliethoff, "Biomass combustion in fluidized bed boilers: potential problems and remedies," Fuel Processing Technology, vol. 90, no. 1, pp. 21-50, 2009.

[24] A. Kumar, D. D. Jones, and M. A. Hanna, "Thermochemical biomass gasification: a review of the current status of the technology," Energies, vol. 2, no. 3, pp. 556-581, 2009.

[25] T. Nussbaumer, "Combustion and co-combustion of biomass," in Proceedings of the 12th European Biomass Conference, vol. I, pp. 31-37, 2002.

[26] J. A. Miller and C. T. Bowman, "Mechanism and modeling of nitrogen chemistry in combustion," Progress in Energy and Combustion Science, vol. 15, no. 4, pp. 287-338, 1989.

[27] C. P. Fenimore, "Formation of nitric oxide in premixed hydrocarbon flames," Symposium (International) on Combustion, vol. 13, no. 1, pp. 373-380, 1971.

[28] B. Leckner and M. Karlsson, "Gaseous emissions from circulating fluidized bed combustion of wood," Biomass and Bioenergy, vol. 4, no. 5, pp. 379-389, 1993.

[29] S. van Loo and J. Koppejan, Handbook of Biomass Combustion and Co-Firing, vol. 32 of IEA Bioenergy Task, 2002.

[30] A. V. Bridgewater, Progress in Thermochemical Biomass Conversion. Handbook, vol. 1, John Wiley \& Sons, 2008.

[31] S. Mamphweli, Implementation of a 150 KVA biomass gasifier system for community economic empowerment in South Africa [Ph.D. thesis], University of Fort Hare, 2009.

[32] A. Moilanen, "Thermogravimetric characterisations of biomass and wastes for gasification processes," Tech. Rep. 607, VTT Publications, 2006.

[33] M. Lapuerta, J. J. Hernández, A. Pazo, and J. López, “Gasification and co-gasification of biomass wastes: effect of the biomass origin and the gasifier operating conditions," Fuel Processing Technology, vol. 89, no. 9, pp. 828-837, 2008.

[34] S. Gaqa, S. Mamphweli, D. Katwire, and E. Meyer, "The properties and suitability of various biomass/coal blends for cogasification purposes," Journal of Sustainable Bioenergy Systems, vol. 4, no. 3, pp. 175-182, 2014. 

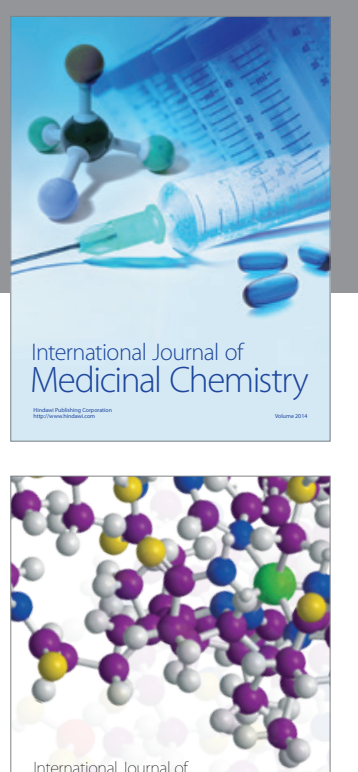

Carbohydrate Chemistry

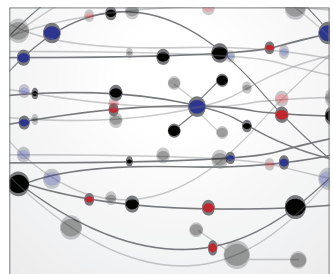

The Scientific World Journal
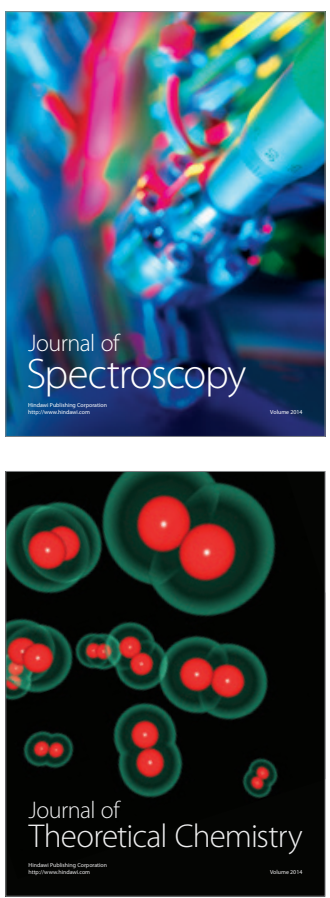
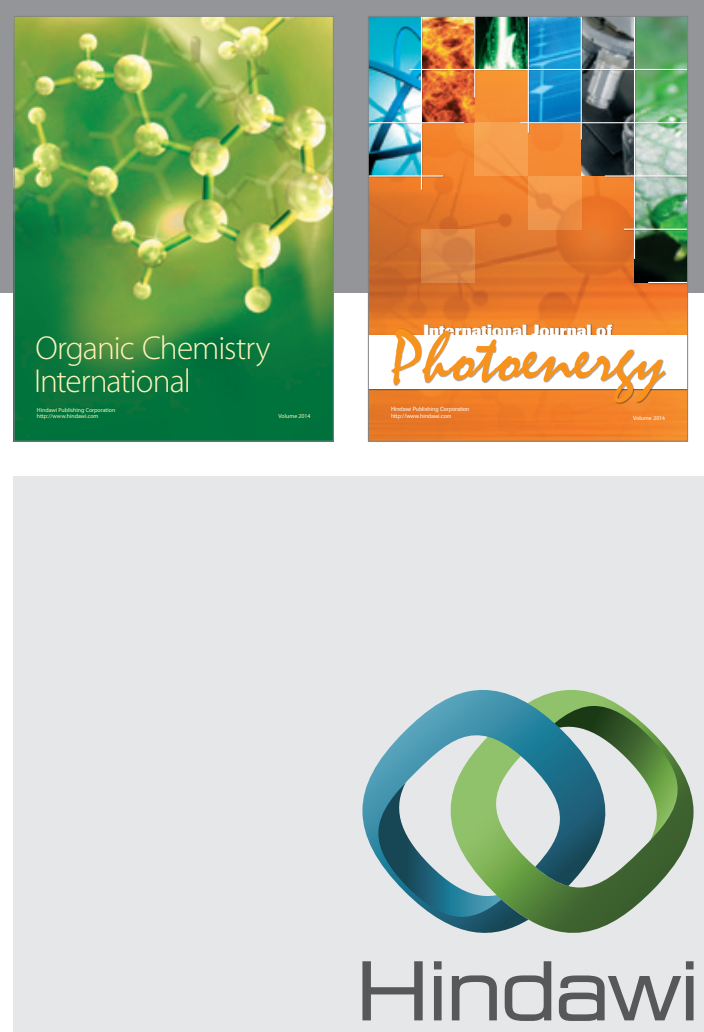

Submit your manuscripts at

http://www.hindawi.com

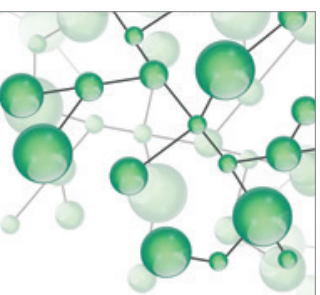

International Journal of

Inorganic Chemistry

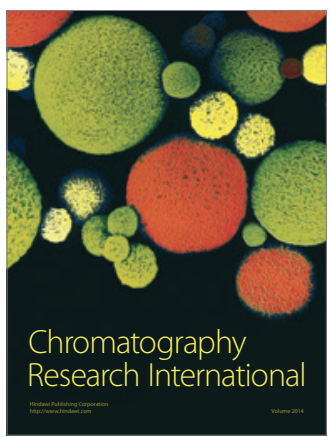

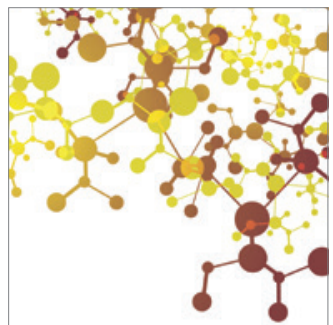

Applied Chemistry
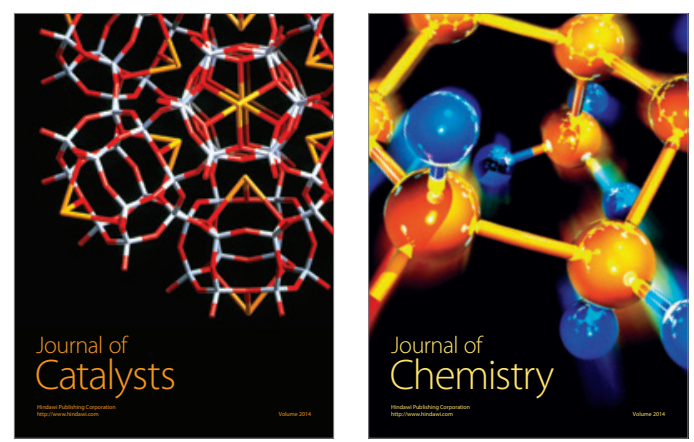
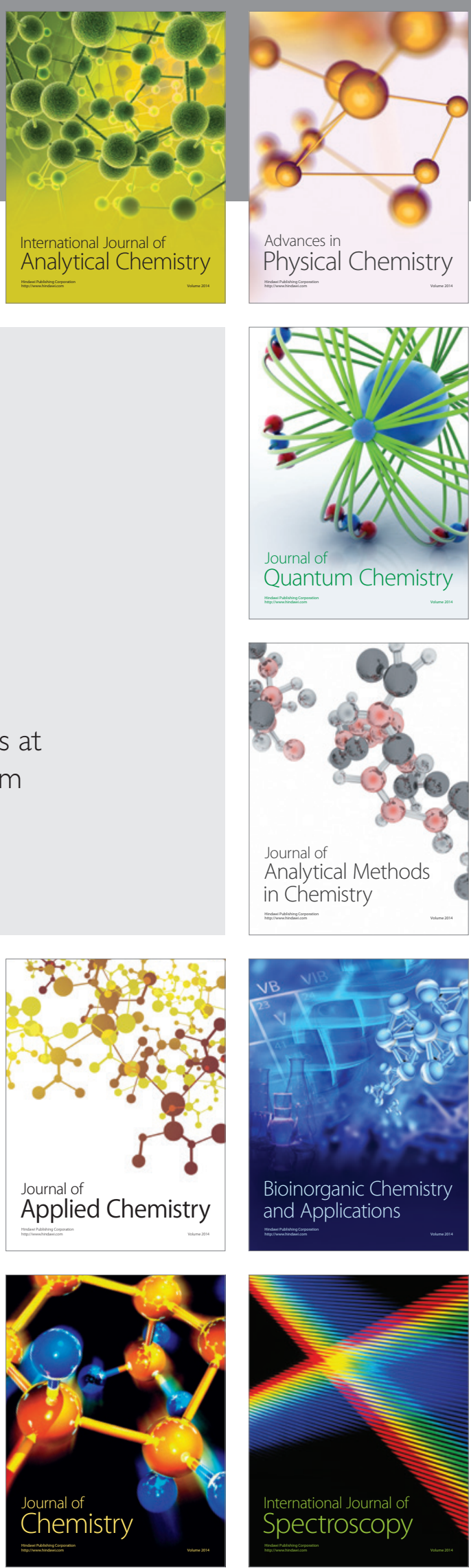